\title{
PENANAMAN KONSEP ASTRA BRATHA DALAM PENDIDIKAN MORAL ANTIKORUPSI
}

\author{
Ni Nyoman Ayu Suciartini \\ uci_geg@yahoo.com
}

\begin{abstract}
Abstrack
Leadership in Hinduism is closely related to ethics. The nature and attitude of a leader is a determinant of the success or failure of a leader in running the wheels of government. Local wisdom is owned by the Balinese Hindu community is very positive to stem the behavior of corruption both in leadership on campus and when plunging in the community. Corruption behavior should not be interpreted as culture and society antipati against it. His young son as the next generation of the nation must be saved from corruption pratik increasingly rampant. The most basic and contextual, which is very close to the life of the community that is tangent to the culture, local wisdom of a society. This local wisdom plays an important role to realize the prevention of corruption is more leverage. Local wisdom asta bratha, 8 good leadership traits according to Hindu concept can be an alternative to moral education in elementary, middle, upper, and college. The nature of this leadership will be a strong moral foundation in education to lead students to a better life without corruption and the goals of the nation and the state can be maximized.
\end{abstract}

Keywords: moral education, anticorruption education

\section{PENDAHULUAN}

Korupsi lagi, korupsi lagi. Sepertinya, kabar tentang korupsi bukan hal mengejutkan dan bukan hal biasa. Anak muda, khususnya mahasiswa tidak menganggap korupsi sebagai hal penting lagi. "Sudah biasa", "Ah, bosan dengar pejabat setiap hari ditangkap", begitulah kalimat-kalimat yang biasa terlontar dari mahasiswa ketika ada yang menyinggung tentang perilaku korup di negeri ini. Anak muda, khususnya mahasiswa antipasti, cenderung berpikir bahwa korupsi akan menjadi budaya di Indonesia, lambat laun. Perspektif seperti ini tentu tidak bisa dibiarkan atau diendapkan lebih lama. Anak muda Indonesia harus memandang bahwa korupsi bukan sebagai budaya atau akan menjadi budaya. Korupsi harus diperangi, seperti terorisme, narkoba, kejahatan seksual, sama seperti kejahatan yang bisa memecah belah bangsa ini.

Berdasarkan data dari Komisi Pemberantasan Korupsi (KPK) diperoleh data Per 30 Juni 2017, di tahun 2017 KPK melakukan penanganan tindak pidana korupsi dengan rincian: penyelidikan 48 perkara, penyidikan 51 perkara, penuntutan 41 perkara, inkracht 40 perkara, dan eksekusi 40 perkara. Dan total penanganan perkara tindak pidana korupsi dari tahun 2004-2017 adalah penyelidikan 896 perkara, penyidikan 618 perkara, penuntutan 506 perkara, inkracht 428 perkara, dan eksekusi 454 perkara. Juru Bicara Komisi Pemberantasan Korupsi ( KPK) Febri Diansyah menyebut, sekitar 71 orang yang 
berada dalam rentang usia 31 hingga 40 tahun diproses hukum oleh KPK karena kasus korupsi.Data tersebut dari total perkara yang diproses KPK sejak 2003 hingga akhir 2016. Menjadi pekerjaan rumah yang berat juga kenapa anak-anak muda, darahdarah muda yang diharapkan menjadi aktor perubahan di masingmasing institusi kemudian terjebak, atau menjadi bagian atau pelaku tindak pidana korupsi itu sendiri. Apa yang bisa diharapkan bangsa ini ketika anak mudanya justru mudah terjerat rayuan, kemilau harta, juga kedudukan yang goyah?

Pemuda dan tindak korupsi harus segera dipisahkan. Ini permasalahan serius, penting, dan mendesak. Mereka harus disadarkan sejak dini untuk mencegah bibit-bibit membudayakan perilaku korupsi dimanapun, baik saat kuliah, maupun bekerja. Pemuda khususnya mahasiswa adalah aset paling menentukan kondisi zaman tersebut dimasa depan. Mahasiswa salah satu bagian dari gerakan pemuda.

Peran penting mahasiswa tersebut tidak dapat dilepaskan dari karakteristik yang mereka miliki, yaitu: intelektualitas, jiwa muda dan idealisme. Dengan kemampuan intelektual yang tinggi, jiwa muda yang penuh semangat, dan idealisme yang murni terlah terbukti bahwa mahasiswa selalu mengambil peran penting dalam sejarah perjalanan bangsa ini. Dalam beberapa peristiwa besar perjalanan bangsa ini telah terbukti mahasiswa berperan penting sebagai agen perubahan (agent of change). Faktanya fenomena korupsi selalu tidak berhenti menggrogoti negeri kita, korupsi merupakan kejahatan yang bukan hanya merugikan negara tetapi juga masyarakat. Artinya keadilan dan kesejahteraan masyarakat sudah mulai terancam. Maka saatnya mahasiswa sadar dan bertindak. Hal ini terutama dimulai dari kesadaran masing-masing mahasiswa yaitu menanamkan kepada diri mereka sendiri bahwa mereka tidak boleh melakukan tindakan korupsi walaupun itu hanya tindakan sederhana, misalnya terlambat datang ke kampus, menitipkan absen kepada teman jika tidak masuk atau memberikan uang suap kepada para pihak pengurus beasiswa dan macam-macam tindakan lainnya. Memang hal tersebut kelihatan sepele tetapi berdampak fatal pada pola pikir dan dikhawatirkan akan menjadi kebiasaan bahkan yang lebih parah adalah menjadi sebuah karakter. Selain kesadaran pada masing-masing mahasiswa maka mereka juga harus memperhatikan kebijakan internal kampus agar dikritisi sehingga tidak memberikan peluang kepada pihak-pihak yang ingin mendapatkan keuntungan melalui korupsi. Misalnya ketika penerimaan mahasiswa baru mengenai biaya yang diestimasikan dari pihak kampus kepada calon mahasiswa maka perlu bagi mahasiswa untuk mempertanyakan dan menuntut sebuah transparasi dan jaminan yang jelas dan hal lainnya. Jadi posisi mahasiswa di sini adalah sebagai pengontrol kebijakan internal universitas.

Berawal dari kegiatankegiatan sederhana di lingkungan terdekat seseorang, perilaku korupsi bisa dicegah sedini mungkin. Budaya takut, disiplin, dan bertanggung jawab merupakan tugas penting untuk kembali dibangkitkan di tengah tontonan yang tidak mendidik 
di masyarakat dengan banyaknya elite politik yang justru tertangkap, terjerat, bahkan tidak jarang mereka lantas menjadi jera.

Berdasarkan latar belakang di atas, permasalahan yang diangkat dalam penelitian ini adalah bagaimana peranan budaya, khususnya kearifan lokal masyarakat Bali yang memercayai konsep Asta Brata, delapan sifat keteladanan kepemimpinan dalam mencegah perilaku maupun tindak korupsi di perguruan tinggi yang diintegrasikan ke dalam mata kuliah dan proses belajar mengajar.

$\begin{array}{llr}\text { Tujuan } & \text { khusus } & \text { dalam } \\ \text { penelitian } & \text { ini } & \text { adalah }\end{array}$
mendeksripsikan peranan budaya, khususnya kearifan lokal masyarakat Bali yang memercayai konsep Asta Brata, delapan sifat keteladanan kepemimpinan dalam mencegah perilaku maupun tindak korupsi di perguruan tinggi yang diintegrasikan ke dalam mata kuliah dan proses belajar mengajar.

Ruang lingkup atau batasan penelitian dalam penelitian ini adalah menganalisis proses belajar mengajar di kelas dalam mata kuliah Pancasila, Bahasa Indonesia, juga kelas Teknologi Informasi di lingkungan STMIK STIKOM Bali yang memuat penanaman nilai-nilai kearifan lokal, khususnya Asta Brata dalam proses belajar mengajar untuk mencegah perilaku korupsi.

Penelitian ini penting
dilakukan sebab permasalahan
pencegahan korupsi lebih penting
dewasa ini untuk dilakukan. Perilaku
korupsi jangan sampai dimaknai
sebagai budaya dan masyarakat
antipati terhadapnya. Anak mudanya

sebagai generasi penerus bangsa harus diselamatkan dari pratik korupsi yang kian merajalela. Hal yang paling mendasar dan kontekstual, yang sangat dekat dengan kehidupan masyarakat yaitu hal yang bersinggungan dengan budaya, kearifan lokal suatu masyarakat. Kearifan lokal inilah yang berperan penting untuk dapat mewujudkan pencegahan korupsi yang lebih maksimal.

Penelitian ini menggunakan penelitian sejenis yang digunakan sebagai refrensi agar dapat terlihat kebaruan penelitian ini dibandingkan penelitian sebelumnya. Penelitian berjudul Pendidikan Anti Korupsi Di Sman 1 Sigaluh Banjarnegara oleh Lissa Solehatun Rosida tahun 2016 menunjukkan bahwa pendidikan anti korupsi di SMAN 1 Sigaluh melalui beberapa tahapan yaitu dengan budaya sekolah dan integrasi ke dalam mata pelajaran, hal ini diakukan dengan cara menerapkan nilai-nilai pendidikan anti korupsi kedalam seluruh kegiatan sekolah baik pembelajaran maupun diluar pembelajaran ini bertujuan untuk membentuk sikap anti korupsi pada peserta didik dan menghasilkan lulusan dengan tingkat kejujuran yang tinggi sehingga SMAN 1 Sigaluh dapat ikut berperan dalam memberantas korupsi sejak dini. Penelitian lain yang digunakan sebagai penelitian sejenis yaitu Pendidikan Anti Korupsi Terintegrasi dalam Pembelajaran PKn untuk Menanamkan Karakter Kejujuran di SMP oleh Mukhamad Murdiono pada tahun 2016 yang menunjukkan bahwa upaya yang dilakukan oleh guru PKn dalam mengintegrasikan pendidikan antikorupsi dalam pembelajaran PKn 
dengan cara menyisipkan nilai-nilai antikorupsi dalam materi pembelajaran yang relevan. Kendala yang dihadapi oleh guru PKn antara lain terkait dengan permasalahan waktu dan kesulitan dalam memilih metode pembelajaran yang tepat.

Berdasarkan penelitian di atas, terdapat perbedaan dengan penelitian yang dilakukan. Perbedaan tersebut nampak dari variabel yang diteliti, subjek, juga pendekatan yang digunakan. Penelitian terkait pendidikan antikorupsi di perguruan tinggi dalam sudut pandang kearifan lokal Bali, khususnya yang menyangkut sikap kepemimpinan atau Asta Brata merupakan hal yang baru, penting, dan menarik untuk diteliti dan dikaji lebih mendalam.

\section{PEMBAHASAN}

Pendidikan anti korupsi adalah program pendidikan tentang korupsi yang bertujuan untuk membangun dan meningkatkan kepedulian warganegara terhadap bahaya dan akibat dari tindakan korupsi. Target utama pendidikan anti korupsi adalah memperkenalkan fenomena korupsi yang mencakup kriteria, penyebab dan akibatnya, meningkatkan sikap tidak toleran terhadap tindakan korupsi, menunjukan berbagai kemungkinan usaha untuk melawan korupsi serta berkontribusi terhadap standar yang ditetapkan sebelumnya seperti mewujudkan nilai-nilai dan kapasitas untuk menentang korupsi dikalangan generasi muda. Di samping itu, siswa maupun mahasiswa juga dibawa untuk menganalisis nilai-nilai standar yang berkontribusi terhadap terjadinya korupsi serta nilai-nilai yang menolak atau tidak setuju dengan tindakan korupsi. Karena itu pendidikan antikorupsi pada dasarnya adalah penanaman dan penguatan nilai-nilai dasar yang diharapkan mampu membentuk sikap antikorupsi pada diri peserta didik.

Dharma (2003) secara umum menyampaikan tujuan pendidikan anti-korupsi adalah: (1) pembentukan pengetahuan dan pemahaman mengenai bentuk korupsi dan aspekaspeknya; (2) pengubahan persepsi dan sikap terhadap korupsi; dan (3) pembentukan keterampilan dan kecakapan baru yang ditujukan untuk melawan korupsi. Dengan ketiga tujuan itu dapat dilihat bahwa pendidikan antikorupsi meskipun mempunyai sasaran utama sebagai pendidikan nilai akan tetapi tetap meliputi ketiga ranah pendidikan sebagaimana dikemukakan oleh Bloom yaitu pengembangan ranah kognitif, afektif dan psikomotor siswa. Berdasarkan rumusan yang ditentukan oleh komisi pemberantasan korupsi (KPK), ada sembilan nilai dasar yang perlu ditanamkan dan diperkuat melalui pelaksanaan pendidikan antikorupsi di sekolah, yaitu nilai kejujuran, adil, berani, hidup sederhana, tanggung jawab, disiplin, kerja keras, hemat dan mandiri. Nilai-nilai ini sebenarnya ada di masyarakat sejak zaman dahulu, dan termuat secara jelas dalam dasar falsafah negara Pancasila, namun mulai tergerus oleh budaya konsumerisme yang dibawa oleh arus modernisasi dan globalisasi.

Sesuai dengan tujuan yang hendak dicapai, maka pelaksanaan pendidikan antikorupsi di sekolah perlu memperhatiakan beberapa hal 
terkait (Modern Didactic Center, 2006) di antaranya adalah :

\section{Pengetahuan tentang korupsi.}

Untuk memiliki pengetahuan yang benar dan tepat tentang korupsi, siswa perlu mendapatkan berbagai informasi yang, terutama informasi yang memungkinkan mereka dapat mengenal tindakan korupsi dan juga dapat membedakan antara tindakan kejahatan korupsi dengan tindakan kejahatan lainnya. Untuk itu pembahasan tentang kriteria, penyebab dan akibat korupsi merupakan materi pokok yang harus diinformasikan pada siswa. Di samping itu siswa juga memiliki argumen yang jelas mengapa perbuatan korupsi dianggap sebagai perbuatan yang buruk dan harus dihindari. Analisis penyebab dan akibat dari tindakan korupsi pada berbegai aspek kehidupan manusia, termasuk aspek moralitas akan memberi siswa wawasan tentang korupsi yang lebih luas. Pada akhirnya berbagai alternatif yang dapat ditempuh untuk menghindari korupsi dapat menjadi inpirasi bagi siswa tentang banyak cara yang dapat dilakukan dalam memberantas korupsi. Kesemua ini merupakan modal dasar dalam penanaman atau pembentukan sikap dan karakter antikorupsi. Berdasarkan pengetahuan yang dimiliki tersebut diharapkan siswa mampu untuk menilai adanya perilaku korup dalam masyarakat atau institusi disekitarnya. Karena itu pemberian informasi tentang korupsi bukanlah untuk memberikan informasi sebanyak mungkin kepada siswa, melainkan informasi itu diperlukan agar siswa mampu membuat pertimbangan pertimbangan tertentu dalam menilai. Dengan kata lain berdasarkan informasi dan pengetahuannnya tentang korupsi siswa mampu menilai apakah suatu perbuatan itu termasuk korupsi atau tidak, dan apakah perbuatan tersebut dikategorikan baik atau buruk. Dengan pertimbangan tersebut selanjutnya siswa dapat menentukan perilaku yang akan diperbuatnya.

\section{Pengembangan sikap}

Sebagai pendidikan nilai dan karakter, pendidikan antikorupsi memberi perhatian yang besar pada pengembangan aspek sikap siswa. Sikap adalah disposisi penilaian yang diberikan terhadap suatu objek yang didasarkan atas pengetahuan, reaksi afektif, kemauan dan perilaku sebelumnya akan objek tersebut (Fishbean, \& Ajzen 1973).). Kesemua elemen diatas saling berhubungan dan saling bertukar tempat misalnya reaksi afektif dibayangi oleh perilaku yang biasa dilakukan. Karena itu sikap yang pro pada korupsi bukanlah sebuah kategori saja melainkan juga mengandung hal lainnya . Perubahan pada satu elemen akan merubah pula elemen yang lainnya. Misalnya menghilangkan intensi dan perilaku mungkin akan merubah kognisi, sikap dan reaksi afektif. Oleh karena itu ketika memberikan informasi tentang korupsi, guru berusaha mengembangkan sikap berdasarkan kognisi. Untuk itu siswa harus memiliki kognisi atau pengetahuan yang benar dan dipahami secara baik, sehingga pengetahuan itu bisa bertahan lama dalam memorinya dan dapat dipergunakan setiap kali mereka akan membuat pertimbangan tertentu. Disamping itu keterlibatan yang intens dalam aktifitas yang mengandung nilai-nilai antikorupsi 
juga akan mengembangkan sikap yang sesuai dengan nilai tersebut.

\section{Perubahan sikap}

Merubah sikap yang telah dimiliki sebelumnya merupakan pekerjaan dan tugas yang tidak gampang dan terkadang menimbulkan rasa frustasi. Apalagi jika sikap yang telah dimiliki tersebut berlawanan dengan sikap yang dikehendaki guru atau pendidik, misalnya sikap yang menganggap curang dalam ujian adalah hal yang biasa dikalangan siswa, atau mencontoh tugas kawan untuk diakui sebagai tugas sendiri merupakan hal yang lumrah. Hal ini akan berlanjut terus dengan sikap terhadap fenomena dalam masyarakat seperti menyogok polisi karena melanggar peraturan lalu lintas, dan lain sebagainnya. Pendidikan antikorupsi menghendaki sikapsikap seperti ini perlu untuk dirubah agar sesuai dengan nilai-nilai dasar antikorupsi. Untuk itu diperlukan pola dan strategi perubahan sikap yang bisa dipakai dari berbagai sumber misalnya untuk membentuk persepsi tentang korupsi yang berlawanan dengan persepsi yang dimiliki siswa dapat dilakukan dengan menyajikan informasi secara tak terduga melaui permainan atau parodi. Strategi lain dalam merubah sikap adalah dengan didasarkan pada fakta bahwa pengetahuan dan sikap disimpan dalam tempat atau memori yang berbeda, karena itu diperlukan waktu untuk mencapai keduanya, artinya proses pengetahuan berubah menjadi sikap memerlukan waktu yang cukup panjang. Karena itu jika ada sikap yang pro pada korupsi sebaiknya tidak diserang secara langsung atau diatasi dengan cara persuasif. Dalam waktu panjang sikap tersebut akan berganti dengan sendirinya jika informasi yang mendiskreditkan korupsi disajikan dalam cara yang bermakna dan memancing siswa untuk berpikir secara kritis tentang fenomena tersebut. Karena disinilah reaksi yang disebut postponement effect, (Innerney, 2006), dimana pada awalnya informasi tidak akan dipercayai tapi kemudian pengetahuan yang benar akan mengatasi reaksi afektif.

4. Perspektif Moral dan Konvensional

Pendidikan anti korupsi didasarkan pada pendidikan nilai yang tidak begitu membedakan secara tegas antara dua regulasi sosial yaitu moralitas dan konvensi. Dalam perspektif moral, perilaku yang baik dikatakan baik karena diterima secara universal dan merupakan kewajiban semua orang tanpa melihat apa yang dipikirkan orang secara individual. Selanjutnya dari perspektif moral suatu tindakan dinilai sebagai baik atau buruk dengan melihat pada konsekuensinya, apakan tindakan itu menyakitkan bagi orang laian, atau membawa kerusakan, atau melanggar rasa keadilan bagi semua orang. Selanjutnya kualitas suatu tindakan mungkin ditentukan oleh niat seseorang. Suatu tindakan tidak dapat diterima jika niat atau maksud pelakunya itu buruk, meskipun pada suatu situasi hasilnya tidak jelek atau buruk, dan sebaliknya dapat dipertimbangkan jika niatnya baik meskipun hasilnya gagal. Konvensi adalah norma yang didasarkan pada kesepakatan bersama yang ada pada suatu masyarakat pada suatu waktu tertentu, jadi tidak menjadi wajib bagi komunitas lain karena itu tidak 
universal. Dalam kehidupan nyata moralitas dan konvensi saling terkait. Prinsip moral yang umum turun menjadi norma seperti jangan mencuri, jangan berbohong, bertindak adil pada orang lain. Sedangkan pelanggaran terhadap konvensi yang dianggap sangat penting oleh suatu komunitas seperti menghormati orang yang telah mati, bisa juga menjadi pelanggaran moral karena itu menyakiti perasaan orang lain. Dengan kata lain moralitas dan konvensi berada pada konsep yang berbeda dan juga punya logika yang berbeda pula. Pendidikan antikorupsi sebaiknya memperhatikan perbedaan antara moralitas dengan konvensi. Dari perspektif konvensional apapun boleh dilakukan selama tidak dilarang, sedangkan dari perspektif moral suatu tindakan dilihat apakah itu ada dalam norma atau tidak. Perspektif moral lebih sensitif melihat kerusakan yang ditimbulkan atas seseorang sedangkan perspektif konvensi lebih melihat pada pelanggaran kesepakaran, konsistensi dan ekspektasi dari pemilik otoritas. Pelanggaran terhadap prinsip moralitas menimbulkan rekasi afektif yang lebih kuat. Perilaku manusia dalam menanggapi pelanggaran moral atau konvensi juga berbeda. Jika mereka melanggar prinsip moral mereka minta maaf atau mencoba mencari pembenaran atau alasan dari tindakan mereka itu, tetapi prinsip moral itu sendiri tidaklah dipertanyakan. Sementara kalau mereka melanggar konvensi maka mereka akan mengkritisi sumber norma tersebut. Karena itu manusia tahu secara instingtif mana yang moralitas dan mana yang konfensi.

$$
\text { Berdasarkan pandangan }
$$

Kohlberg (dalam Slavin, 2004) tentang tahap-tahap perkembangam moral siswa dan penerimaannya atas konvensi, maka pendidikan antikorupsi, sebaiknya dilaksanakan sesuai dengan kematangan perkembangan moral yang dimiliki siswa. Siswa sekolah menegah atas yang telah berusia antara 14 sampai dengan 17 tahun dapat diberi penjelasan bahwa standar perilaku antikorupsi adalah wajib bagi setiap orang dalam posisi apapun untuk mempertahankan sistem sosial yang ada. Satu hal yang paling penting adalah korupsi itu dinilai jahat dilihat dari perspektif moral dan konvensi. Lebih lanjut Aspin (2007) juga mengemukakan bahwa apapun juga nilai yang ingin dimasukan dalam pendidikan, maka pendidikan menyangkut moral adalah hal yang utama, karena itu merupakan bagian dari kewajiban untuk mempersiapkan generasi muda memasuki dunia yang menghendaki perilaku lebih baik dari yang pernah ada. Oleh karena itu pendidikan yang memperkuat moralitas peserta didik haruslah ditangani oleh institusi pendidikan secara serius.

\section{Pengembangan Karakter Antikorupsi}

Pendidikan antikorupsi bukanlah seperangkat aturan perilaku yang dibuat oleh seseorang dan harus diikuti oleh orang lain. Sebagaimana halnya dengan kejahatan lainnya, korupsi juga merupakan sebuah pilihan yang bisa dilakukan atau dihindari. Karena itu pendidikan pada dasarnya adalah mengkondisikan agar perilaku siswa sesuai dengan tuntutan masyarakat. Agar perilaku tersebut dapat menjadi karakter siswa, maka beberapa langkah bisa dilakukan dalam pendidikan antikorupsi, diantaranya 
adalah: a. Melatih siswa untuk menentukan pilihan perilakunya. Untuk itu siswa harus diberi tahu tentang hak, kewajiban dan konsekuensi dari tindakan yang dilakukannya. Jika dalam diskusi siswa mengemukakan pilihannya terhadap sesuatu maka guru bisa memberikan beberapa alternatif lain, misalnya untuk mendapatkan nilai bagus banyak cara yang bisa dilakukan. Berdasarkan alternatif pilihan tersebut siswa bisa menentukan mana yang baik atau yang buruk. Jika siswa mampu memutuskan sendiri berdasarkan pilihan yang dibuatnya, maka mereka juga berani mengatakan tidak atau ya terhadap sesuatu. b. Memberi siswa kesempatan untuk mengembangkan pemahaman yang luas dengan menciptakan situasi yang fleksibel dimana siswa bisa berkerjasama, berbagi, dan memperoleh bimbingan yang diperlukan dari guru. Karena itu kegiatan dalam menganalisis kasus, diskusi, bermain peran atau wawancara siswa merupakan situasi yang akan mengembangkan karakter antikorupsi pada diri siswa. c. Tidak begitu terfokus pada temuan fakta seperti, berapa persen PNS yang terlibat korupsi, berapa banyak uang Negara yang hilang dikorupsi pertahun atau berapa hukuman yang tepat untuk pelaku korupsi dsb. Hal itu juga penting tetapi yang lebih penting adalah bagaimana membantu siswa menemukan sumber informasi, seperti bagaimana dan dengan cara apa informasi bisa dikumpulkan, seberapa penting informasi yang didapat, pengetahuan apa yang bisa diandalkan, dan posisi apa yang harus dipilih dsb. Siswa diminta untuk menganalisis posisi yang diambilnya, menyatakan pilihanya dan mengapa posisi lain tidak diambil. Dengan melatih siswa menggunakan tehnik berpikir kritis pertanyaan tersebut akan dapat dijawabnya. d. Melibatkan siswa dalam berbagai aktifitas sosial disekolah dan di lingkungannya. Ini ditujukan untuk menanamkan rasa tanggung jawab dan respek pada orang lain dalam rangka melatih mereka untuk berbagi tanggung jawab sosial dimana mereka tinggal. Bukan berarti karakter lain tidak penting tetapi dengan mengemukakan rasa tanggung jawab dan respek pada orang lain akan mengurangi rasa egoisme dan mementingkan diri sendiri yang pada umumnya banyak dimiliki para koruptor.

\section{Konsep Kearifan Lokal, Asta Brata dalam Mencegah Perilaku Korupsi}

Kepemimpinan atau leadership secara umum merupakan perilaku yang memengaruhi manusia baik perorangan maupun kelompok, untuk dapat melaksanakan tugas dan kewajibannya dengan sebaikbaiknya serta dituntut untuk kerjasama yang baik sehingga dapat mencapai tujuan organisasi yang diinginkan. Kepemimpinan menurut Hindu sangat banyak dibahas dalam cerita-cerita Hindu salah satunya dalam Manawadharmasastra dijelaskan bahwa seorang pemimpin harus menanamkan delapan sifat dewa di dalam dirinya yang disebut Asta Brata. Asta Brata artinya delapan ajaran utama tentang kepemimpinan yg merupakan petunjuk Sri Rama kepada Bharata (adiknya) yg akan dinobatkan menjadi raja Ayodya. Asta Brata disimbulkan dengan sifat-sifat dari alam semesta yang patut dijadikan pedoman bagi setiap Pemimpin yaitu 
1. INDRA BRATA: seorang pemimpin hendaknya seperti hujan yaitu senantiasa mengusahakan kemakmuran bagi rakyatnya dan dalam setiap tindakannya membawa kesejukan dan penuh kewibawaan.

2. YAMA BRATA: seorang pemimpin hendaknya meneladani sifat-sifat Dewa Yama yaitu berani menegakan keadilan menurut hukum atau peraturan yg berlaku demi mengayomi masyarakat.

3. SURYA BRATA: seorang pemimpin hendaknya memiliki sifat-sifat seperti Matahari (surya) yg mampu memberikan semangat dan kekuatan pada kehidupan yg penuh dinamika dan sebagai sumber energi.

4. CANDRA BRATA: seorang pemimpin hendaknya memiliki sifat-sifat seperti bulan yaitu mampu memberikan penerangan bagi rakyatnya yg berada dalam kegelapan/kebodohan $\quad \mathrm{dg}$ menampilkan wajah yg penuh kesejukan dan penuh simpati shg masyarakatnya merasa tenteram dan hidup nyaman.

5. BAYU BRATA: seorang pemimpin hendaknya ibarat angin (Maruta), senantiasa berada ditengah-tengah masyarakatnya, memberikan kesegaran dan selalu turun ke bawah untuk mengenal denyut kehidupan masyarakat yg dipimpinnya.

6. KUWERA BRATA = Pemimpin hendaknya harus bijaksana mempergunakan dana atau uang serta selalu

$\begin{array}{lr}\text { ada hasrat } & \text { untuk } \\ \text { mensejahtrakan masyarakat } & \\ \text { dan tidak menjadi pemboros } & \text { pemban } \\ \text { yang akirnya rapat } & \text { dan } \\ \text { merugikan Negara } & \text { dan } \\ \text { Masyarakat. } & \end{array}$

7. BARUNA BRATA: seorang pemimpin hendaknya bersifat seperti samudra yaitu memiliki wawasan yg luas, mampu mengatasi setiap gejolak dengan baik, penuh kearifan dan kebijaksanaan.

8. AGNI BRATA: seorang pemimpin hendaknya memiliki sifat mulia dari api yaitu mendorong masyarakatnya untuk berpartisipasi dalam pembangunan, tetap teguh dan tegak dalam prinsip dan menindak/menghanguskan yg bersalah tanpa pilih kasih.

Kepemimpinan dalam Hindu merupakan hal yang sangat terkait dengan etika. Sifat dan sikap yang dimiliki seorang pemimpin merupakan penentu berhasil atau tidaknya seorang pemimpin dalam menjalankan roda pemerintahan. Kearifan lokal yang dimiliki masyarakat Hindu Bali ini sangat positif untuk membendung perilaku korupsi baik dalam kepemimpinan di kampus maupun ketika terjun di masyarakat.

\section{PENUTUP}

Kepemimpinan dalam Hindu merupakan hal yang sangat terkait dengan etika. Sifat dan sikap yang dimiliki seorang pemimpin merupakan penentu berhasil atau tidaknya seorang pemimpin dalam menjalankan roda pemerintahan. Kearifan lokal yang dimiliki masyarakat Hindu Bali ini sangat 
positif untuk membendung perilaku korupsi baik dalam kepemimpinan di kampus maupun ketika terjun di masyarakat. Perilaku korupsi jangan sampai dimaknai sebagai budaya dan masyarakat antipati terhadapnya. Anak mudanya sebagai generasi penerus bangsa harus diselamatkan dari pratik korupsi yang kian merajalela. Hal yang paling mendasar dan kontekstual, yang sangat dekat dengan kehidupan masyarakat yaitu hal yang bersinggungan dengan budaya, kearifan lokal suatu masyarakat. Kearifan lokal inilah yang berperan penting untuk dapat mewujudkan pencegahan korupsi yang lebih maksimal. Kearifan lokal asta bratha, 8 sifat kepemimpinan yang baik menurutkonsep Hindu bisa menjadi alternatif pendidikan moral di sekolah dasar, menengah, atas, maupun perguruan tinggi. Sifat kepemimpinan ini akan menjadi landasan moral yang kuat dalam pendidikan untuk mengarahkan siswanya kepada kehidupan yang lebih baik tanpa korupsi dan tujuan berbangsa dan bernegara bisa digapai dengan maksimal.

\section{DAFTAR PUSTAKA}

Dharma, Budi. 2013. Korupsi dan Budaya (dalam Kompas Cetak 25 Oktober 2013). Jakarta: Kompas Cetak.

Kementrian Pendidikan dan Kebudayaan. 2011. Pendidikan Anti Korupsi untuk Perguruan Tinggi.

Murdiono, Muhammad. 2016. Pendidikan Anti Korupsi Terintegrasi dalam Pembelajaran PKn untuk Menanamkan Karakter
Kejujuran di SMP (artikel Jurnal Socia). Yogyakarta: Socia.

Solehatun, Lissa Rosida. 2016. Pendidikan Anti Korupsi Di Sman 1 Sigaluh Banjarnegara. Skrispi (tidak diterbitkan). IAIN Purwokerto.

Syarbaini Amirullah dan Muhamad Arbain. 2014. Pendidikan AntiKorupsi, Alfabeta: Bandung.

Wibowo Agus. 2013. Pendidikan Anti Korupsi di Sekolah. Yogyakarta:Pustaka Pelajar. 